\title{
Visions of Europe. \\ Emerging challenges for the European project in the aftermath of the 2014 European Parliament elections
}

\section{Introduction}

The 2008 economic crisis redefined the political relationship between European citizens and the European Union, between the member states and EU institutions, and between countries within the European Union, unveiling economic, social and cultural differences across member states and within their domestic polities that had previously remained largely concealed. The crisis led to the re-emergence of critical nodes of the European project, questioning the very principles adhered to by member states and European citizens.

Like other scholars (Bolgherini 2016; Fabbrini 2015), we interpret the period that followed the economic crisis as a critical juncture in the process of European integration - the third, according to Fabbrini, after the two that followed the end of the Second World War and the end of the Cold War. European integration has been considered as "perpetually in crisis" (Baglioni and Hurrelmann 2016, 104) and, indeed, a permanent status of crisis and the management thereof are a constitutional feature of democratic regimes (Urbinati 2013). However, the current phase stands out as something different from the ordinary strains and pressures that are part and parcel of democratic life. Rather than being the manifestation of the typical tensions and dynamics, the processes of European integration and EU decision-making have evidenced the need for major reform of the European Union's institutional architecture and modus operandi, and presented national and European leaders with choices that will have a lasting impact (Capoccia and Kelemen 2007; Pierson 2004) on the Union's nature and identity.

A commonly held (but not consensus ${ }^{1}$ ) view is that what started as an exogenous financial crisis evolved into an economic and then sovereign debt crisis in the weakest EU member states. This, in turn, ended up engulfing the monetary union (Majone 2014b), leading to a profound political crisis for the EU as a whole: a crisis of leadership, legitimacy and, ultimately, purpose. Whilst much has already been said

${ }^{1}$ According to a group of leading European economists, the Euro crisis 'should not be thought of as a government crisis in its origin - even though it evolved into one'. See http://www.voxeu.org/article/ez-crisis-consensus-narrative. 
on the individual 'dimensions of crisis' outlined above, far less is known on how they interweave and on their long-term effects, notably their impact on the EU's institutional architecture, on the politicisation of the European public sphere, on the wider dynamics of representation that underpin these processes, and on the political systems and polities of the member states. With this special issue, and in this introduction, we aim to contribute to the understanding of these themes. We do so by offering, first, an interpretative overview of the key dimensions of crisis that are currently challenging the EU. Drawing on such premises, we move on to appraise the 2014 European Parliament election - understood as a turning point for the EU - with reference to the findings of the six articles in this collection. We then conclude with some reflections on what the trends discussed in the special issue tell us about the future 'visions of Europe' and the associated implications for research designs.

\section{A crisis of leadership}

The ways in which the initial economic crisis and the subsequent Eurozone crisis were tackled by the EU demonstrated an inability of EU leaders to act swiftly, cohesively and for the long term. Whilst there has been a European response - or rather a succession of European responses - they have been partial. ${ }^{2}$ They were achieved "slowly and reluctantly" (Hall 2014, 1231) and weighted disproportionately on Southern member states, on whom adjustment costs were largely concentrated (see Hall 2014). Most of all, as recently argued by a group of prominent European economists under the Vox-EU platform, the response measures did not focus on the underlying roots of the crisis, without a consensus on which the necessary long-term solution is unlikely to emerge. ${ }^{3}$

Agreement on the causes and, as a result, on the solutions to the Eurozone crisis has proved impossible, in part, because of the different mindsets of EU leaders, embedded in distinct national economic doctrines and political economy histories (Hall 2014) and, in part, because of the divergent national interests and unpalatability

2 They have resulted in a composite and incremental mix of bailout packages, dedicated European funds (the European Financial Stability Fund and, subsequently, the European Stability Mechanism), enhanced monitoring of national economic policies (the European semester), and coordination of national fiscal policies (the Fiscal Compact) (Begg 2015b; Crum and Curtin 2015).

3 Avent R. The euro crisis was not a government-debt crisis, The Economist, 23 November 2015 (online edition). See also http://www.voxeu.org/article/ez-crisisconsensus-narrative. 
of redistributive choices for the short-term 'losers', namely the wealthier Northern European (creditor) member states.

Despite the number of measures progressively introduced to strengthen the architecture of the Economic and Monetary Union (EMU) and the further reforms announced by the Commission in a recent Communication (European Commission 2015), the road ahead looks tortuous and uncertain. The Communication was intended to implement the so-called Five Presidents Report, published in June 2015 by the Presidents of the European Commission, the European Council, Eurogroup, the European Central Bank and the European Parliament (Juncker 2015). ${ }^{4}$ However, both the Five Presidents Report and the ensuing Communication "watered down" a number of provisions that had already been foreseen in the previous Four Presidents Report $^{5}$ issued in 2012 (Begg 2015a), demonstrating an awareness of the challenges in implementation. Despite this toning down - which led to criticism about the incisiveness of the package - many of the provisions proposed are still "likely to encounter resistance from a number of EU countries" (Begg 2015a). The prospect of an Economic and Monetary Union strengthened (eventually) through a fully-fledged political and fiscal union remains implausible.

Even leaving aside the Eurozone crisis, the predominance of domestic interests at the expense of unified visions of Europe has been underlined by the way in which the EU has handled other recent crises. These include the refugee emergency, the instability in the Middle East and Northern Africa (from which the former descends), the crisis in the Eastern border following from Russia's illegal annexation of parts of Ukraine, and the security threat posed by Islamic terrorism. For example, the refugee emergency, which according to Amnesty International (2015) is the most serious refugee crisis faced by Europe since the Second World War, has been met with only disjointed, ad hoc responses, largely informed by national interests. EU solutions ranged from a continued reliance on the Mediterranean programmes (in principle, intended as economic development programmes) and on EU-Turkey cooperation, to reallocations of financial resources from existing budgetary headings, such as unspent amounts under European Cohesion policy (Crisp 2016). However, a key concern for many national political leaders, especially in the Northern and Eastern member states, has been to make sure

4

${ }^{5}$ In 2012, the President of the European Parliament was not included. 
that the number of refugees flowing to their countries would remain within domestically acceptable figures.

The way the EU responded to the Ukraine-Russia conflict presents another telling example of the difficulty in providing EU-wide responses. The second anniversary of the annexation of Crimea and Sevastopol by Russia was marked by a declaration published on politico.eu by the Foreign Ministers of the Baltic and Nordic States, restating the need to 'remain vigilant' and constantly monitor the nonrecognition policy and EU sanctions already in place (Wallström et al. 2016). More incisive, EU-wide political action was clearly seen as out of question.

\section{A crisis of legitimacy}

A second issue, which is closely connected with the leadership crisis outlined above, concerns legitimacy. The responses given to the economic and Euro crises highlighted a growing contradiction between, on the one hand, the 'emergency', largely technocratic, EU-level decision-making (White 2015; Statham and Trenz 2015), and, on the other hand, the increased salience of the EU in the public debates within the member states. The crisis, and the associated EU response, contributed to the Europeanisation of public discourses in the EU member states, and in so doing they increased the saliency of the EU in domestic political debates, bringing renewed centrality to EU institutions and policies (Leupold 2016). This has improved the ability of European citizens to apportion 'blame' for EU-level decisions to the EU rather than to national parliaments. However, it has not translated into an improved ability of EU citizens to precisely identify those actors (European-level parties and politicians as decision-makers) that should be punished (Hobolt and Tilley 2014). Put simply, European citizens are unable to throw the (European) rascals out, insofar as it is difficult for them "to identify which parties are responsible for the current policy outcomes and which parties offer an alternative" (Hobolt 2014, 1531).

Partly to address this problem, the 2014 European Parliament elections were held under altered rules. The European Parliament, through an own resolution, ${ }^{6}$ managed to introduce an important change to the appointment procedure of the President of the European Commission. It did so by inviting EU Parties to appoint lead candidates, or Spitzencandidaten, who would (in the view of the European

\footnotetext{
${ }^{6}$ Resolution 22 November 2012, see Hobolt 2014.
} 
Parliament's interpretation of the provisions of the Lisbon Treaty) be appointed Commission President in the event of electoral victory (Hobolt 2014; Schmitt, Hobolt, and Popa 2015). Thus, for the first time, voters had the opportunity to clearly identify the nominees running for the head of the European executive. The aim of this was twofold: to exploit the mobilisation effect of personalisation (Musella and Webb 2015; Calise 2015) in order to create a stronger connection with citizens, and to bridge the EU accountability gap (Gattermann, de Vreese, and van der Brug 2016).

However, evidence available to date suggests that the impact of this change on voting behaviour has been limited, albeit diversified across member states (Hobolt 2015). "[T]urnout remained low at 42.6 per cent, government parties were the losers and smaller parties the winners, and the introduction of lead candidates seemed to have gone unnoticed by most citizens" (Hobolt 2015, 6; see also Hobolt 2014 and Schmitt, Hobolt and Popa2015). The introduction of Spitzencandidaten has had an effect on informed citizens, but it did not succeed in mobilising the less interested or disenfranchised EU voters (Gattermann, de Vreese, and van der Brug 2016). As in previous European Parliament elections, rather than sanctioning EU political parties for their actions, voters' concerns about the handling of the crisis and dissatisfaction with the austerity policies were channelled through a vote for Eurosceptic or outright anti-EU parties. ${ }^{7}$ In other words, what was being punished was the EU, not its political decision-makers, just as in 2009 (Hobolt and Tilley 2014). ${ }^{8}$

The complex and piecemeal procedures through which the EU measures to tackle the Eurozone crisis were designed and subsequently put in place further contributed to the difficulty for European citizens' to identify in clear terms the political actors ultimately responsible for decisions (Crum and Curtin 2015). The subdivision of competences and the balance of powers between different European institutions are obscure for the public, rendering EU decision-making a black box in the eyes of the layperson. For example, the Commission displays a considerable degree of discretion in the exercise of its functions under the European semester, yet its activities remain largely hidden from public scrutiny (Crum and Curtin 2015).

\footnotetext{
${ }^{7}$ Predominantly left-wing parties in the debtor, Southern member states, and radical right-wing parties in Northern Europe, see Hobolt 2015.

${ }^{8}$ It has been recognised, however, that even though the change did not have a direct effect on turnout, it did contribute to increased media attention over the European Parliament elections, attributing more salience to the EU in domestic public debates (Schulze 2016), thus reinforcing elements of accountability.
} 
The role of the European Parliament in the dialogue with the Councils and the Commission remains secondary. Similarly secondary is the role of national Parliaments in sanctioning the collective decisions taken by their governments in the Council or in informing national budgets and the implementation of country-specific recommendations (Crum and Curtin 2015). The procedures put in place to prevent excessive macroeconomic imbalances mean that national budgets are now submitted to Brussels before going to the national Parliaments (Majone 2014a).

In sum, the way the EU has responded to the economic and Eurozone crises manifests a number of accountability and, as a result, legitimacy deficits, and "it is not only the citizens that are being excluded from the debate about the future of the Eurozone" (Majone 2014a, 1221), but also national governments and parliaments. Many national governments had to agree to severe austerity measures and structural reform programmes (concerning the welfare state and labour market) not as a result of domestic political choices but as the outcome of negotiations with external actors: the 'Troika', the International Monetary Fund (IMF), and other member states' governments. The fact that a number of national governments, constrained by the pressures of international financial markets, had to redefine their policy agendas according to such external demands has been viewed as an interference which has undermined "democratic self-determination" and impacted on "citizens sense of selfefficacy", increasing their "dissatisfaction with democracy" (Armingeon and Guthmann 2014, 424). In Greece, for example, in July 2015, when the bailout deal was being finalised about one week after the Greek referendum had rejected further austerity, "the hashtag \#thisisacoup trended on twitter" (Buttonwood 2015).

Scholarly debates have long focussed on whether the EU is characterised by a democratic deficit (Føllesdal and Hix 2006). This debate has grown in parallel with the expansion of the EU's supranational competences via successive treaty reforms. In this debate, legitimation has been characterised mainly by democratic input or substantive output (Hobolt 2015; Majone 2014a); at the present juncture, the EU appears to be failing on both fronts. As a result, in continuation with a trend whose first signs emerged in the 2009 European Parliament elections, 'Europe' has shifted from traditional marginality to a new, mainly negative, centrality boosted by 'party contestation' (Shuck et al. 2011) - a contestation that has spilled over into domestic arenas. Eurosceptic parties, in particular, have reinforced their presence not only in the European Parliament, but also in national and sub-national assemblies (most 
recently in Germany, in the regional elections held in March 2016). At the same time, Eurosceptic rhetoric is becoming increasingly evident, even within mainstream political parties. This signals a growing and bipartisan loss of trust in the European project at the grassroots level, as well as a widening of the fracture between political élites (national and European) and EU technocracies, on the one hand, and the lay European citizen on the other hand. But it also alters the internal political and party dynamics of the EU member states in a manner that, in our view, is not yet fully appreciated and begs further investigation.

\section{A crisis of purpose}

The leadership crisis within the EU outlined above goes hand in hand with a loss of shared purpose. The Euro, for example, which was originally conceived as a tool to foster an ever-closer political union, has become a goal in itself in the most recent narratives of European leaders (Majone 2014b). On one level, this may not be surprising if, despite "the bold political vision set out in the founding treaty" of an ever-closer political union, monetary and market integration have been the actual core of "the reality of European integration" (Hobolt and de Vries 2016, 22.8). However, this shift in focus can be interpreted as a resignation from even the intention to pursue the treaty's ambitious political goals. Taken to extremes, it can be read as a sign that EU leaders are abdicating their very role.

More recently, the Brexit negotiations can be seen as a further example of a lack of common vision by EU leadership on what the EU should be about. Primarily engaged in finding workable solutions to accommodate UK requests, so as to avert the loss of an important member and the political and economic consequences that this would entail, EU leaders failed to engage in a thorough reflection about the systemic reforms that would be necessary in an increasingly contested - but also ever-expanding ${ }^{9}$ - Union (Zuleeg 2016), and on what this would mean for the future configuration of the Union under both scenarios (Brexit or Brexin).

At the same time, some of the founding values and principles upon which the European project was built, foreseen by the treaty, such as the free movement of

9 Whilst negotiations with Turkey are effectively suspended, the accession negotiations are progressing with regard to Albania, the Republic of Macedonia, Montenegro and Serbia, with Bosnia and Herzegovina and Kosovo as potential candidates. 
people and the attainment of prosperity for all across the continent, are, if not overtly questioned, at least being set aside. For instance, the terrorist attacks in France in January and November 2015 have accelerated the transformation of a set of controversial proposals linked to border management into actual policies, despite opposition concerning data protection (Bossong and Carrapico 2016), and to suspensions of the provision of the Schengen Agreement. Thus, emergency-driven responses have prevailed over democratically established priorities. All of this shows how "Europe is again at a crossroad, not only economically but even more so institutionally and politically. Joschka Fisher's question in 2000, 'Quo Vadis Europa?' has not yet received a proper answer" (Meny 2014, 1336).

In many respects, it could be argued that rather than having stopped at a crossroad, European integration is taking steps backwards in the institutionalisation process that transformed the economic community into a political union in the making. Such retrenchment is showing the fragility of progress realised through an integration 'by stealth': a process that benefitted from a long, but not perpetual, favourable economic context, and that appears ill-suited to a much-enlarged EU, where growing diversity is making the costs of EU integration increasingly visible (Majone 2014a). In truth, the process of integration is becoming increasingly differentiated too (Tekin 2012), but this is actually exacerbating the territorial cleavages between member states. For example, the divides between creditor and debtor countries, and between members and non-members of the Eurozone, are becoming starker (Majone 2014a). And this is happening at a time when the internal divides within the member states are also deepening, as shown by the momentum gained by independentist parties. The presence of secessionist and independentist parties is spreading across many EU member states (Elias and Tronconi 2011; Hepburn and Elias 2011; Hepburn 2009), signalling the emergence of internal fractures that further problematise the process of integration (Laible 2008). Against such a complex backdrop, the future political direction of the EU appears increasingly uncertain, and the risk that the EU will turn into a 'club of clubs' (Majone 2014a; Majone 2014b) seems tangible.

\section{Visions of Europe: key issues and the challenges ahead}

The analysis developed in the previous sections illustrates how, in the current context, the EU project is facing multiple institutional, political and democratic 
challenges. As noted above, the lack of a cohesive and effective EU political leadership, the declining trust in the EU and the on-going alteration of political and party dynamics within the member states are placing Europe and its institutions under considerable strain. The aim of this collection of articles emerges from the need to shed light on the roots, manifestations and implications of such pressures. To achieve this, we take the 2014 European Parliament elections as a starting point for analysis. Such an approach rests on the view that the 2014 European Parliament electoral round epitomises, in a most profound way, the idiosyncrasies implicit in the EU project. Taking place at a time when the effects of the economic crisis and the consequent dissatisfaction with austerity measures were still sharply felt by EU citizens, the 2014 elections were an important test for the European Union and for the institution of democracy within and across EU member states. In many respects, although European Parliament elections are often described as 'second order', this time around the vote for the European Parliament seemed to challenge such a view. In spite of, or perhaps due to, the multiple crises described above, which are undermining the very foundations of the European Union as a political project, the EU is playing an increasingly central role in the public debate and has been thrust centre stage. Albeit framed mainly in a negative sense (i.e. with more reference to flaws than to virtues), the 2014 European Parliament elections coincided with an increased politicisation of the EU and with a profound alteration of the dynamics of representation underpinning the European sphere, which in turn affected domestic political and party systems. The articles in this collection provide fresh insights on these issues, as is discussed in the following sections.

\section{The politicisation of the $\mathbf{E}$ and the Europeanisation of public debates}

The paradigm of second-order elections (Reif and Schmitt 1980), which has until recently acted as an effective interpretive key to understand voting behaviour in European elections, should perhaps be reassessed when considering the 2014 European Parliament elections. In many respects, the European Union is no longer just a supranational political player, detached from the daily life of citizens. On the contrary, as noted by Schmitt and Teperoglou (2015), even if electoral choices in the 2014 European Parliament elections reflect the logic of the second-order election paradigm, there are also indicators of change. The 2014 elections became a critical 
contest, in which "the EU divide has become more significant, polarised and important in determining voting choices" (Schmitt and Teperoglou 2015, 304).

Several scholars have argued that the EU is undergoing a rapid process of politicisation which, in turn, is redefining its role. De Wilde et al. $(2015,4)$ claim that such increased politicisation of the EU could be empirically identified through three main dimensions: "(a) the growing salience of European governance, involving (b) a polarisation of opinion, and (c) an expansion of actors and audiences engaged in monitoring EU affairs". Such traits of politicisation can be readily found within the public debates of EU member states (ibidem). Similar traits of politicisation are noted by Hoeglinger (2016): (a) the polarisation of attitudes, (b) the intensification of the public debate (saliency), and (c) the connection of the contested issues to pre-existing basic political concerns. Crucially, both conceptualisations of the politicisation of the EU converge in underlining the key role of the public sphere.

The politicisation of the EU and the Europeanisation of the public debate is discussed in Marinella Belluati's article. Taking into account five newspapers from five EU countries (France, Germany, Italy, Spain, UK), Belluati analyses the dynamics of media coverage during the European Parliament election campaigns. The results of this work suggest that the focus on the EU was mainly domestically oriented, that is, centred on national political actors and issues. Nonetheless, the research also reveals that the focus of public debate was on the EU, mostly driven by Eurosceptic stances, parties and leaders. The EU, in other words, was certainly more central in domestic public debates, but it was generally framed in a negative sense.

\section{Dynamics of representation}

Dynamics of political representation are rapidly changing within and across the EU, putting the increasingly problematic nature of the relationship between EU citizens and institutions under the spotlight. The structural weaknesses that inhibit the ability of EU institutions to respond to external challenges, such as the economic and humanitarian crises, have already been discussed in the preceding sections. The key point here is that such processes have considerably undermined the legitimacy of the EU. Hence, it is important to investigate further the motifs and effects that underpin the changing relationship between the EU, its member states and its citizens. This 
collection offers three contributions that investigate such questions, adopting different analytical perspectives.

Firstly, the economic crisis has become the casus belli around which the relationship between member states and EU institutions, on the one hand, and between citizens and the EU, on the other, has been redefined. Stefano Rombi's article adopts the traditional perspective of economic voting to investigate the nature of the electoral behaviour in European competitions. By taking into account four European Parliament elections in all EU member states, his work analyses the effect of macroeconomic indicators (unemployment) on voting behaviour. The results confirm the applicability of the paradigm of economic voting to EU elections. This is interesting, especially in the light of the increased politicisation of the EU noted above. As Bellucci, Lobo and Lewis-Beck (2012) have argued, economic globalisation and the involvement in decision-making of a wide range of (political and economic) supranational and international actors have eroded traditional governmental powers in the steering of the economy, consequently decreasing the accountability of domestic governments vis-à-vis their electors. In line with this, Rombi's work finds that the voters - following media and political parties' rhetoric perceive the EU as the culprit of economic decline and are less likely to blame their national governments for the consequences of the economic crisis (see also -Lobo and Lewis-Beck 2012). Overall, Rombi's study shows that the economic crisis does impact on voters' choices. Within this frame, unemployment emerges as the most significant macroeconomic variable. Crucially, this affects the electoral behaviour not only of those directly affected by unemployment, but also of the voters who perceive the economic environment within the EU as being unfavourable more generally.

Secondly, Gabriela Borz focuses on political representation in connection with European integration. Her analysis aims at clarifying the link between citizens and political parties' opinions on European integration. Following cost-benefit logic, the results of her study show that perceived benefits facilitate a voter-party match, while perceived costs - especially if high - drive the match between Eurosceptic voters and like-minded parties. The most interesting result concerns 'indifferent voters', namely those who prefer the status quo, and who seem to be able to vote for both pro- and anti-integration parties. This category of voters can be more commonly found in 'old member states', and it includes citizens who are less satisfied with the 
way in which the EU works in practice but who, more generally, have a positive view of the European Union. These outcomes, based on 2009 ESS (European Social Survey) data, provide an interesting interpretative frame for the 2014 European Parliament elections, in that they show how indifferent voters can shift towards Eurosceptic parties as a result of the perceived costs of integration.

Thirdly, Fabio Sozzi looks at the dynamics of political representation, considering the relationship between electoral rules and MEPs 'constituency representation', measured through the lens of parliamentary questions. To achieve this, the author examines the behaviour of Italian and French MEPs, who are representative of different systems in terms of ballot structure and district magnitude. Sozzi's analysis explores a large dataset of 5,343 written parliamentary questions asked by Italian and French MEPs during the sixth term of the European Parliament (2004-2009). The results confirm the hypothesis that MEPs' behaviour is affected by electoral rules. If the electoral system provides a stronger connection between candidates and their supporters, MEPs will have more incentives to be constituencyoriented in their positions. The analysis illustrates how French MEPs, who are elected through closed ballots, have a feebler link with their constituency, which is mirrored in their behaviour in Parliament. On the other hand, Italian MEPs have more incentives to cultivate their personal reputation; hence they pay more attention to constituency demands. This, in turn, has profound implications for the way in which citizens perceive political representation at EU level in the two countries. Sozzi shows that electoral rules do have direct consequences on representation, which suggests that there is a need for more research on MEP behaviour and electoral rules in relation to other countries.

\section{The impact on domestic political and party systems}

As already highlighted, we contend that the economic and Eurozone crises, and the EU response to them, are having important effects on the domestic political systems of EU member states. First, the economic crisis significantly affected the territorial and sectoral composition of public expenditure, with negative consequences for countries' long-term growth prospects (Grisorio and Prota 2015; Bubbico and Catalina-Rubianes 2015). This impact has been particularly severe for the more vulnerable people and territories, as is testified by the exacerbation of social inequalities and regional disparities across the EU (European Commission 2014). It is 
reasonable to expect that these socially and territorially differentiated effects of the crisis would impact on voting behaviour.

Second, and related, the austerity packages and structural reforms have led to a re-centralisation of a substantial amount of policy competences in a number of countries (Bolgherini 2016; Muro 2015; Council of European Municipalities and Regions 2013). A question here is the degree to which this will translate into new political centre-periphery cleavages. The 2015 regional elections in Italy, for example, highlighted a rise in local lists and a decline in mainstream political parties (Vampa 2015).

Third, as has been noted, the rise of Euroscepticism was a feature of the 2014 elections, also in countries that had long been amongst the most convinced EU supporters. Particularly interesting insights on this can be drawn from the analysis of the 2014 European Parliament election results in Italy where, for the first time, Eurosceptic parties gained more than 50 per cent of the votes (circa 20 per cent more than in 2009) ${ }^{10}$ (Huysseune 2010; Conti 2014), demonstrating a shift of public opinion from Europhile to Eurosceptic positions. This shows a sharp decline in citizens' trust in the EU and its institutions. Yet, somewhat paradoxically, the trust that Italian citizens place in the European Union continues to remain significantly higher than that enjoyed by the Italian parties, Parliament, trade unions, State and regional authorities. ${ }^{11}$ This raises questions about the true nature of the Italian antiEU turn and whether it could be linked to a more generalised populist reaction.

These themes are tackled by two of the contributions in this volume. To start with, Riera and Russo examine the generational and territorial cleavages through a comparative analysis of Italy and Spain. They appraise the electoral performance of two new parties - the Five Star Movement, in Italy, and Podemos, in Spain - in the 2014 European Parliament elections, analysing data at municipal, rather than

${ }^{10}$ In the 2009 EU Elections, all together, Eurosceptic parties gained $16.7 \%$ of votes. In detail: the Northern League (Lega Nord, LN), 10.2\%, Communist Refoundation (Rifondazione Comunista, RC) 3.4\%, Left Ecology and Freedom (Sinistra ecologia e Libertà, SEL) $3.1 \%$. In 2014, the Eurosceptic votes rose to $51.8 \%$, thanks in part to the performance of the Five Star Movement: (Movimento 5 Stelle, M5S) 21.2\%, Go Italy (Forza Italia, FI) 16.8\%, Northern League 6.2\%, Tsipras List 4\% and Italian Brothers (Fratelli d'Italia, FDI) 3.7\%.

${ }^{11}$ Demos and Pi survey, December 2015: http://www.demos.it/rapporto.php. Only 5 per cent of those surveyed declared to have considerable trust in Italian parties, 10 per cent in the Italian Parliament and 22 per cent in the Italian State, against 30 per cent who declared to have considerable trust in the European Union. 
constituency, level. They argue that focussing on the municipal level allows for a more accurate analysis of local characteristics and aspects of voting behaviour (especially in connection with the economic crisis) that could not be detected at constituency level. The study shows: the presence of unsatisfied political demands (high abstention rates) and voters' volatility in both countries; considerable territorial variation, in both countries, in the electoral performance of the two new parties across municipalities; and that the economic crisis had a marked (positive) impact on the electoral affirmation of the two parties, which, however, is differentiated across the two countries.

Caiani and Graziano look at the rise of populism in the context of European Parliament elections. Going beyond the debate on theoretical definitions of populism, they find that focussing on empirical cases allows an appreciation that populism can manifest itself in multiple ways. The authors argue that, in order to be fully understood, populism should be considered not as a "syndrome to be cured" but as an observable phenomenon which may concern all political parties present in a given domestic political community. To substantiate this claim, the authors concentrate on the case of Italy, and they appraise the interaction between Italian political parties and populism traits in a diachronic analysis based on a four-dimensional classification of populism (populism index) in the context of three European Parliament elections in 2004, 2009 and 2014. Through a systematic examination of Euromanifestos and party statutes, their analysis demonstrates that the crisis triggered a consolidation of populist traits across the Italian party system, leading to: the emergence of a new populist party (the Five Star Movement); the strengthening of the electoral performance of the Northern League (presently the most populist Italian party, according to the scholars' index); and the enhancement of populist features in other pre-existing political parties, with the notable exception of the Italian Democratic Party (contradicting the findings of Biorcio 2015). Further, Caiani and Graziano suggest that the financial crisis acted as an 'exogenous shock' that facilitated the emergence and consolidation of populist traits. The denunciation of the crisis and accusations against the EU and its institutions for failing to provide a suitable response feature strongly in Euromanifestos. Thus, the study confirms the link between populism and Euroscepticism and political protest proposed by Canovan (1999). Despite focussing on the Italian case, Caiani and Graziano's work is also remarkable in that it does not simply offer a 'snapshot' of populism in Italy but also 
offers a method to appraise the degree of populism present in any given political system, adding to the study of such phenomena in other countries.

\section{Conclusions}

Through an examination of the 2014 (and, in some cases, preceding) European Parliament elections, the articles in this special issue provide new evidence on the linkage between the economic crisis and a number of EU-level political and institutional developments, including EU politicisation and Europeanisation of domestic frames. Whilst the crisis contributed to increasing the salience of the EU, at the same time it also delegitimised it. Responses to the economic crisis were perceived as not only technocratic but also as externally-imposed, bringing to the surface a long-simmering discontent amongst EU citizens that has found an outlet in Euroscepticism and anti-EU voting. The studies presented in this special issue also offer a novel interpretative frame for the 2014 elections. European Parliament elections have traditionally been viewed as second-order elections. This time, however, it was different, citizens did vote with EU issues in mind.

Importantly, the articles in this collection also shed light on the impact that European-level developments are having on the domestic political systems of EU member states, such as the emergence of new parties, the electoral strengthening of Eurosceptic parties, and a discernible increase in populist features across the entire political spectrum (i.e. also in non-populist parties). What is remarkable about the combination of populism and Euroscepticism that emerged as a key feature of the 2014 elections is that it is not simply retrospectively linked to the austerity measures that followed the economic crisis (whose effects are emphasised by several articles in this collection), but that it is also projected towards the future, questioning the role and sovereignty of the EU, and hinting at the need for the creation of new, and often ad hoc, relationships between the EU and its member states.

Whereas the dynamics of electoral behaviour favoured Eurosceptic and populist parties, they also triggered an 'emulation effect' among traditionally Europhile parties that are increasingly adopting critical narratives towards the EU. Thus, despite the growing saliency of Europe in domestic public debates, the EU appears more and more as a jigsaw of diverging domestic interests and agendas. This is not to say that domestic interests never mattered before. Of course, they have always been part and parcel of the construct of Europe, and the EU has played a role 
in safeguarding them. However, in the current context, domestic interests are becoming increasingly polarised and conflicting. This is leading to the emergence of a number of competing visions of Europe, which challenge in a most profound way the idea of the EU as a coherent construct, generating constraints - rather than opportunities - for the integration process. Our overall conclusion is that EU-level and domestic-level developments both reflect and influence each other. Neither can be understood in isolation from the other. In our view, this calls for research designs that bridge different political science subfields, and for more vigorous crossfertilisation between European integration studies, comparative politics and political theory. 


\section{Bibliography}

Amnesty International. 2015. The Global Refugees Crisis. A Conspiracy of Neglect. London: Amnesty International.

Armingeon, Klaus, and Kai Guthmann. 2014. 'Democracy in Crisis? The Declining Support for National Democracy in European Countries, 2007-2011.' European Journal of Political Research 53(3): 423-42.

Baglioni, Sebastian, and Achim Hurrelmann. 2016. 'The Eurozone Crisis and Citizen Engagement in EU Affairs.' West European Politics 39 (1): 104-24.

Begg, Iain. 2015a. Deepening EU Economic Governance: The Next Steps. Europp Blog 4 November 2015. http://blogs.lse.ac.uk/europpblog/2015/11/04/deepening-eueconomic-governance-the-next-steps/ (downloaded 22 March 2016).

Begg, Iain. 2015b. What does the Five Presidents' Report mean for the Future of the Euro? Europp Blog 23 June 2015. http://blogs.lse.ac.uk/europpblog/2015/06/23/whatdoes-the-five-presidents-report-mean-for-the-future-of-the-euro/ (downloaded 22 March 2016).

Bellucci, Paolo, Marina C. Lobo, and Michael S, Lewis-Beck. 2012. 'Economic Crisis and Elections: The European Periphery.' Electoral Studies 31(3): 469-471.

Biorcio, Roberto. 2015. Il populismo nella politica italiana, Milano: Mimesis.

Bolgherini, Silvia. 2016. 'Crisis-driven Reforms and Local Discretion: An Assessment of Italy and Spain.' Italian Political Science Review 46(1): 71-91.

Bossong, Raphael, and Helena Carrapico. (2016). 'The Multidimensional Nature and Dynamic Transformation of European Borders and Internal Security'. In EU Borders and Shifting Internal Security. Technology, Externalization and Accountability, edited by Raphael Bossong and Helena Carrapico, 1-21. Cham: Springer International Publishing.

Bubbico, Rocco Luigi, and Angel Catalina-Rubianes. 2015. 'L'Impatto della Crisi sugli Investimenti Pubblici in Europa. Il Ruolo dei Fondi Strutturali nel Sostegno dei Potenziali di Crescita Regionali.' Rivista Giuridica del Mezzogiorno 1-2: 37-64. 
Buttonwood, Even more on debt and democracy, The Economist, 15 July 2015 (online edition).

Calise, Mauro. 2015. 'The Personal Party: An Analytical Framework.' Italian Political Science Review 45(3): 301-15.

Canovan, Margaret. 1999. 'Trust the people! Populism and the two faces of democracy.' Political Studies 47(1): 2-16.

Capoccia, Giovanni, and R. Daniel Kelemen. 2007. 'The Study of Critical Junctures. Theory, Narrative, and Counterfactuals in Historical Institutionalism.' World Politics 59 (April): 341-69.

Conti, Niccolo. 2014. Party Attitudes Towards the EU in the Member States. London: Routledge.

Council of European Municipalities and Regions. 2013. Decentralisation at a Crossroads. Territorial Reforms in Europe in Times of Crisis. http://www.ccre.org/img/uploads/piecesjointe/filename/CCRE_broch_EN_complete low.pdf (downloaded 25 March 2016).

Crisp James. 2016. 'MEPs find 10 billion for refugees in unspent funds', Euractiv.com, 17 March 2016.

Crum, Ben, and Deirdre Curtin. 2015. 'The Challenge of Making European Union Executive Power Accountable'. In The European Union. Democratic Principles and Institutional Architectures in Times of Crisis, edited by Simona Piattoni, 63-87. Oxford: Oxford University Press.

De Wilde, Pieter, Anna Leupold, and Henning Schmidtke, 2015. 'Introduction: The Differentiated Politicisation of European Governance', West European Politics, 39(1): 3-22.

Elias, Anwen, and Filippo Tronconi. 2011. 'From Protest to Power: Autonomist Parties in Government.' Party Politics 17(4): 505-24.

European Commission. 2014. Investments for Jobs and Growth. Promoting Development and Good Governance across European Regions and Cities. Sixth Report on Economic, Social and Territorial Cohesion. Luxembourg: Publications Office of the European Union. 
European Commission. 2015. Communication from the Commission to the European Parliament, the Council and the European Central Bank on Steps Towards Completing Economic and Monetary Union. Brussels, 21.10.2015, COM(2015) 600 final.

Fabbrini, Sergio. 2015. Which European Union? Europe after the Euro Crisis. Cambridge: Cambridge University Press.

Føllesdal, Andreas, and Simon Hix. 2006. 'Why there is a democratic deficit in the EU: A response to Majone and Moravc-sik.' Journal of Common Market Studies 44(3): 533-562.

Gattermann, Katjana, Claes H. de Vreese, and Wouter van der Brug. 2016. 'Evaluations of the Spitzenkandidaten: The Role of Information and News Exposure in Citizens' Preference Formation.' Politics and Governance 4(1): 37-54.

Grisorio, Maria Jennifer, and Francesco Prota. 2016. 'Public Expenditure in Time of Crisis: Are Italian Policymakers Choosing the Right Mix?' GEN Working Paper B 2016 - 2, March 2016, http://infogen.webs.uvigo.es/WPB/WP1602.pdf (accessed 23 March 2016).

Hall, Peter A. 2014. 'Varieties of Capitalism and the Euro Crisis.' West European Politics 37(6): 1223-43.

Hepburn, Eve, and Anwen Elias. 2011. 'Dissent on the Periphery? Island Nationalisms and European Integration.' West European Politics 34 (4): 859-82.

Hepburn, Eve. 2009. 'Introduction: Re-conceptualizing Sub-state Mobilization.' Regional \& Federal Studies 19 (4-5): 477-99.

Hobolt, Sara B., and James Tilley. 2014. Blaming Europe: Responsibility Without Accountability in the European Union. New York: Oxford University Press.

Hobolt, Sarah B. 2014. 'A Vote for the President? The Role of Spitzenkandidaten in the 2014 European Parliament Elections.' Journal of European Public Policy 21(10): $1528-40$.

Hobolt, Sarah B. 2015. 'The 2014 European Parliament Elections: Divided in Unity?' Journal of Common Market Studies 53 (Annual Review): 6-21. 
Hobolt, Sarah B., and Catherine E. de Vries. 2016. 'Public Support for European Integration.' Annual Review of Political Science. Review in advance posted online on March 2, 2016, doi 10.1146/annurev-polsci-042214-044157.

Hoeglinger, Dominic. 2016. Politicizing European Integration: Struggling with the Awakening Giant. Houndmills: Palgrave Macmillan.

Huysseune, Michel. 2010. 'A Eurosceptic Vision in a Europhile Country: The Case of the Lega Nord.' Modern Italy 15(1):63-75.

Juncker, Jean-Claude. 2015. Completing Europe's Economic and Monetary Union, Report by Jean-Claude Juncker, in close cooperation with Donald Tusk, Jeroen Disselbloem, Mario Draghi and Martin Schultz, 22 June 2015.

Laible, Janet. 2008. Separatism and Sovereignty in the New Europe: Party Politics and the Meanings of Statehood in a Supranational Context. New York: Palgrave McMillan.

Leupold, Anna. 2016. 'A Structural Approach to Politicisation in the Euro Crisis.' West European Politics 39(1): 84-103.

Lobo, Marina C. and Michael S, Lewis-Beck. 2012. 'The Integration Hypothesis: How the European Union Shapes Economic Voting.' Electoral Studies 31(3): 522528.

Majone, Giandomenico. 2014a. 'From Regulatory State to a Democratic Default.' Journal of Common Market Studies 52(6): 1216-23.

Majone, Giandomenico. 2014b. 'Patterns of Post-National Europe: The Future of Integration after the Crisis of Monetary Union'. In Polity and Crisis. Reflections on the European Odyssey, edited by Massimo Fichera, Sakari Hänninen and Kaarlo Tuori, 261-85. Farnham: Ashgate.

Meny, Yves. 2014. 'Managing the EU Crises: Another Way of Integration by Stealth?' West European Politics 37(6): 1336-53.

Muro, Diego. 2015. 'When Do Countries Recentralize? Ideology and Party Politics in the Age of Austerity.' Nationalism and Ethnic Politics 21(1): 24-43.

Musella, Fortunato and Paul Webb. 2015. 'The Revolution of Personal Leaders.' Italian Political Science Review 45(3): 223-6. 
Pierson, Paul. 2004. Politics in Time. Princeton: Princeton University Press.

Reif, Karlheinz, and Hermann Schmitt, 1980. 'Nine Second-order National Elections. A Conceptual Framework for the Analysis of European Election results.' European Journal of Political Research 8(1): 3-44.

Schmitt, Hermann and Efkitia Teperoglou. 2015. 'The 2014 European Parliament Elections in Southern Europe: Second-Order or Critical Elections?' South European Society and Politics 20(3): 287-309.

Schmitt, Hermann, Sarah B. Hobolt and Sebastian A. Popa. 2015. 'Does Personalization increase Turnout? Spitzenkandidaten in the 2014 European Parliament Elections.' European Union Politics 16(3): 347-68.

Schuck, Andreas R.T., Georgios Xezonakis, Matthijs Elenbaas, Susan A. Banducci, and Claes H. de Vreese. 2011. 'Party Contestation and Europe on the News Agenda: The 2009 European Parliamentary Elections.' Electoral Studies 30(1): 41-52.

Schulze, Heidi. 2016. 'The Spitzenkandidaten in the European Parliament election campaign coverage 2014 in Germany, France, and the United Kingdom'. Politics and Governance 4(1): 23-36.

Statham, Paul and Hans-Jörg Trenz. 2015. 'Understanding the Mechanisms of EU Politicization: Lessons from the Eurozone Crisis.' Comparative European Politics 13(3): $287-306$.

Tekin, Funda. 2012. 'Differentiated Integration at Work. The Institutionalisation and Implementation of Opt-Outs from European Integration in the Area of Freedom, Security and Justice.' Studies on the European Union, 6. Nomos, http://www.nomosshop.de/_assets/downloads/9783832971670_lese01.pdf (accessed 23 March 2016).

Urbinati, Nadia. 2013. Democrazia in Diretta. Le nuove sfide alla rappresentanza. Milano: Feltrinelli.

Vampa, Davide. 2015.'The 2015 Regional Election in Italy: Fragmentation and Crisis of Subnational Representative Democracy.' Regional \& Federal Studies 25(4): 365 378.

Wallström, Margot, Marina Kaljurand, Linas Linkevičius, Edgars Rinkēvičs, Timo Soini, and Kristian Jensen. 2016. Europe to Russia: We won't forget Crimea. 
politico.eu, 18 March 2016. http://www.politico.eu/article/europe-to-russia-we-wontforget-crimea/ (accessed 22 March 2016).

White, Jonathan. 2015. 'Emergency Europe'. Political Studies 63(2): 300-318.

Zuleeg, Fabian. 2016. Brexit Averted through EU Reform? EPC Post-Summit Commentary, European Policy Center 22 February 2016. 